Collection: COST Action FP0903 (2010) - Rome (Italy)

"Research, monitoring and modelling in the study of climate change and air pollution impacts on forest ecosystems"

Guest Editors: E Paoletti, J-P Tuovinen, N Clarke, G Matteucci, R Matyssek, G Wieser, R

Fischer, P Cudlin, N Potocic

\section{Is methane released from the forest canopy?}

\author{
Mikkelsen TN, Bruhn D, Ambus P, Larsen KS, Ibrom A, Pilegaard K
}

Laboratory experiments show that rates of $\mathrm{CH}_{4}$ emission from plant material depend exponentially on temperature and linearly on UV irradiance. The UV irradiance shall be spectrally weighted and shorter wavelengths results in higher $\mathrm{CH}_{4}$ emissions. Global upscaling models for estimating aerobic $\mathrm{CH}_{4}$, based on lab results, have be conducted with varying results, but until now field measurements based on profile and eddy covariance measurements have failed to show $\mathrm{CH}_{4}$ emissions from forest canopies. To detect $\mathrm{CH}_{4}$ production or consumption in the canopy of a beech stand we connected a $\mathrm{CH}_{4}$ analyzer to a canopy air profile system that samples air below and above the canopy from seven different heights. A profile system with many vertical sample points can detect gas concentration gradients with a high sensitivity only under conditions with no or little air movements. Under these conditions we found indications of periodic $\mathrm{CH}_{4}$ emissions in the canopy, but more data need to be analyzed before the magnitude of the canopy source of $\mathrm{CH}_{4}$ can be established.

Keywords: Beech, $\mathrm{CH}_{4}$ emission, Profile, Gradient, Flux, Aerobic methane, UV

\section{Introduction}

Methane $\left(\mathrm{CH}_{4}\right)$ is the second most important anthropogenic greenhouse gas, contributing about $30 \%$ to the total net anthropogenic radiative forcing of $1.6 \mathrm{~W} \mathrm{~m}^{-2}$ (Forster et al. 2007). The atmospheric concentration of methane has been increasing since the beginning of the industrial revolution (Etheridge et al. 1998) but the growth rate declined from 1983 until 1999, consistent with an approach to steady state. Superimposed on this decline is a significant interannual variability in growth rate (Dlugokencky et al 2003). From 1999 to 2006, the $\mathrm{CH}_{4}$ concentration was about constant, but in 2007 to 2009, globally averaged $\mathrm{CH}_{4}$ increased

Risø National Laboratory for Sustainable Energy, Technical university of Denmark, Biosystems Division, BIO-309, P.O. Box 49, Frederiksborgvej 399, DK-4000 Roskilde (Denmark)

@ Teis Nørgaard Mikkelsen (temi@risoe.dtu.dk)

Received: Jan 24, 2011 - Accepted: Apr 21, 2011

Citation: Mikkelsen TN, Bruhn D, Ambus P, Larsen KS, Ibrom A, Pilegaard K, 2012. Is methane released from the forest canopy? iForest 4: 200-204 [online 2011-11-03] URL: http://www.sisef.it/iforest/contents/? id=ifor0591-004 again. Dlugokencky et al. (2009) attribute the causes for the current increases to warm temperatures in the Arctic in 2007 and increased precipitation in the tropics in 2007 and 2008

Most of the methane from natural sources in Earth's atmosphere is thought to originate from biological processes in anoxic environments, but a large terrestrial source of $\mathrm{CH}_{4}$ was proposed by Keppler et al. (2006) who observed emissions from vegetation foliage under aerobic experimental conditions. This newly discovered source was estimated to be between 10 and $30 \%$ of the total emissions with a significant temperature dependency (Keppler et al. 2006). Aerobic $\mathrm{CH}_{4}$ emission from foliage has been confirmed by other cantly lower $\mathrm{CH}_{4}$ emissions (Vigano et al. 2008, McLeod et al. 2008, Bruhn et al. 2009, Vigano et al. 2009). In general, rates of $\mathrm{CH}_{4}$ emission were found to depend exponentially on temperature and linearly on UV irradiance. The UV irradiance has to be spectrally weighted and shorter wavelengths results in higher $\mathrm{CH}_{4}$ emissions. (Vigano et al. 2008, McLeod et al. 2008, Bruhn et al. 2009, Vigano et al. 2009).

Studies show that pectin is an important precursor for $\mathrm{CH}_{4}$ production in leaves. A global upscaling model for estimating aerobic $\mathrm{CH}_{4}$ emissions, based on lab results and considering only pectin content as a driver has been conducted recently by groups in the laboratory, but with signifi-
Bloom et al. (2010). Their estimate is one to two orders of magnitude lower than previous estimates of global foliar $\mathrm{CH}_{4}$ emissions by Keppler et al. (2006). Recent studies have reported that pectin is not the only molecular source of UV-driven $\mathrm{CH}_{4}$ emissions and that other environmental stresses may also generate $\mathrm{CH}_{4}$ (Vigano et al. 2008). Consequently, further evaluation of such mechanisms of $\mathrm{CH}_{4}$ generation is needed to confirm the contribution of foliage to the global $\mathrm{CH}_{4}$ budget (Bloom et al. 2010). It is a giant leap, to scale up from simple lab experiments to the globe, and therefore there is a strong need for field measurements to consolidate the upscaling from the lab experiments.

Forest ecosystems are, in relation to area and biomass, the most significant biomes (e.g., Kirschbaum et al. 2006) and consequently are data from forests very central in the understanding of aerobic $\mathrm{CH}_{4}$ emissions. A new and elegant way to show $\mathrm{CH}_{4}$ emissions in situ from forest trees could be by the aid of micrometeorological flux measurements. Until now, field measurements based on eddy covariance have failed to show $\mathrm{CH}_{4}$ emissions from forest canopies (Bowling et al. 2009, Smeets et al. 2009).

To detect any $\mathrm{CH}_{4}$ production in the canopy of a beech stand we connected during autumn a $\mathrm{CH}_{4}$ analyzer to a vertical air sampling system that samples air below and above the canopy from seven heights all in all (profile system). We expected to be able to measure $\mathrm{CH}_{4}$ concentration gradients especially at low wind speeds, when low vertical mixing allows concentration differences to build up.

\section{Material and methods}

The Soroe site is located at $55^{\circ} 29^{\prime} 13^{\prime}$ 'N, $11^{\circ} 38^{\prime} 45^{\prime \prime} \mathrm{E}$ at an elevation of $40 \mathrm{~m}$ above mean sea level in the beech forest "Lille Bøgeskov" near Soro on the island of Zealand, Denmark. It is believed that the forest has never been under plough and that beech trees have been dominating in the area since 2500 B.C. The soils in the area are brown soils classified after the American Soil Taxonomy system as either Alfisols or Mollisols (depending on a base saturation under or over $50 \%$ ) with a $10-40 \mathrm{~cm}$ deep organic layer. The carbon pool in the soil (down to 1 $\mathrm{m}$ depth) is $20 \mathrm{~kg} \mathrm{~m}^{-2}$. The $\mathrm{C} / \mathrm{N}$ ratio is about 20 in the upper organic soil layers falling to about 10 in the lower mineral layers (Pilegaard et al. 2003). In 2003 the trees around the station were 81 years old beech (Fagus sylvatica L.) trees with an average tree height of $25 \mathrm{~m}$. The roughness length is 1.6 $\mathrm{m}$ and the displacement height $19.0 \mathrm{~m}$ (Dellwik \& Jensen 2000). The terrain is flat and there is a homogeneous fetch of $500-2000 \mathrm{~m}$ depending on direction. In 2003 the average tree diameter was $38 \mathrm{~cm}$, the stand density 
Fig. 1 - Illustration of the measuring set up with gas monitors and actual sampling heights for the vertical profile system. See description in the text.

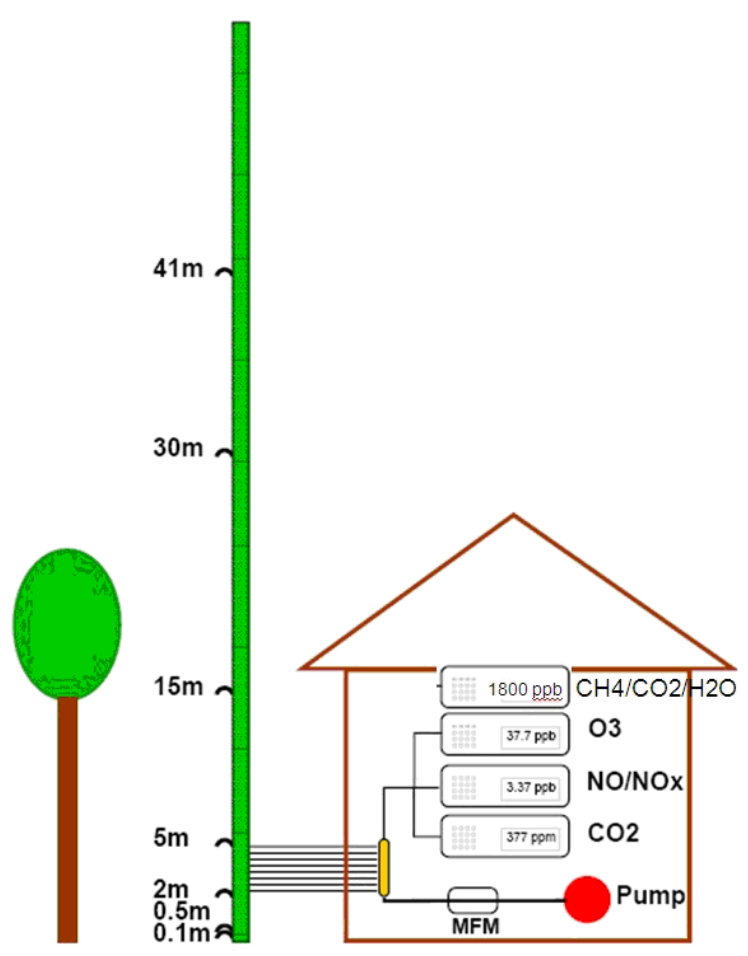

currently measurements are made during 2 minutes from each height. The study was conducted in the autumn 2009 in a senescent canopy just before and during leaf fall $\left(23^{\text {rd }}\right.$ October - $16^{\text {th }}$ November). The $\mathrm{CO}_{2}$ data was extracted from the LGR analyzer were synchronized and matched with $\mathrm{CO}_{2}$ data from the other $\mathrm{CO}_{2}$ analyzer (LICOR - 7000) for verification of the individual measuring heights and times.

\section{Results}

Conditions with low wind speed are needed to detect the build up or depletion of gas concentrations inside a forest canopy gradient. Only during one event during the sampling period did we have sufficiently low wind movements to determine $\mathrm{CH}_{4}$ gradients. In Fig. 2 the relative humidity, PAR, air temperature and friction velocity $\left(u_{*}\right)$ are shown from measurements above the canopy during the event with windless conditions, $31^{\text {st }}$ of October. Stabile air conditions $\left(u_{*}>\right.$ $0.5 \mathrm{~m} \mathrm{~s}^{-1}$ ) are seen from midnight until noon (called analysis period). PAR, air temperature and $u_{*}$ increase from 10:00 while relative humidity (RH) decreases. In Fig. 3A, B was about 283 stems ha $^{-1}$ and the wood increment calculated on the basis of yield tables was approximately $11 \mathrm{~m}^{3} \mathrm{ha}^{-1} \mathrm{yr}^{-1}$; see Pilegaard et al. (2003) for further site details.

The site is equipped with a system with the purpose of measuring profile concentrations of gases such as $\mathrm{CO}_{2}, \mathrm{O}_{3}, \mathrm{NO}$ and $\mathrm{NO}_{2}$ with different monitors (Pilegaard et al. 2003). In autumn 2009, a $\mathrm{CH}_{4}$ new analyzer (LGR, DLT-100, Los Gatos Research, CA, USA), was added to the system. The LGR measures $\mathrm{CH}_{4}, \mathrm{CO}_{2}$ and $\mathrm{H}_{2} \mathrm{O}$ via the cavity-ringdown principle with high precision and in our setup continuously at $1 \mathrm{~Hz}$. The vertical profile system consists of a series of Teflon tubes (inner diameter $4.8 \mathrm{~mm}$ ) with inlets at different heights on a meteorological mast $(0.1 \mathrm{~m}, 0.5 \mathrm{~m}, 1 \mathrm{~m}, 5 \mathrm{~m}, 15 \mathrm{~m}, 30 \mathrm{~m}$ and 41 $\mathrm{m}$ - Fig. 1). The tubes are sets of two different lengths: $25 \mathrm{~m}$ for heights up to $15 \mathrm{~m} ; 50$ $\mathrm{m}$ for heights from $15 \mathrm{~m}$ to $41 \mathrm{~m}$; i.e., at 15 $\mathrm{m}$ both lengths are applied in order to make it possible to investigate tube effects. A constant flow is maintained through the tubes by a diaphragm compressor with a total flow rate of $20 \mathrm{SLPM}$, i.e., $2.5 \mathrm{~L}$ continuously on each tube, monitored by a mass flow meter. PTFE coated valves (Type 117, Bürkert $\mathrm{GmbH} \& \mathrm{Co}$. KG, Ingelfingen, Germany) are installed on the individual tubes to allow the air intake to the monitors to be switched between the different heights (Fig. 1 - Pilegaard et al. 2003).

The forest canopy starts with the lower leaves around $13 \mathrm{~m}$ above the forest floor and ends around the height of $26 \mathrm{~m}$ above the forest floor. The measurement time at each height can be controlled by a computer;

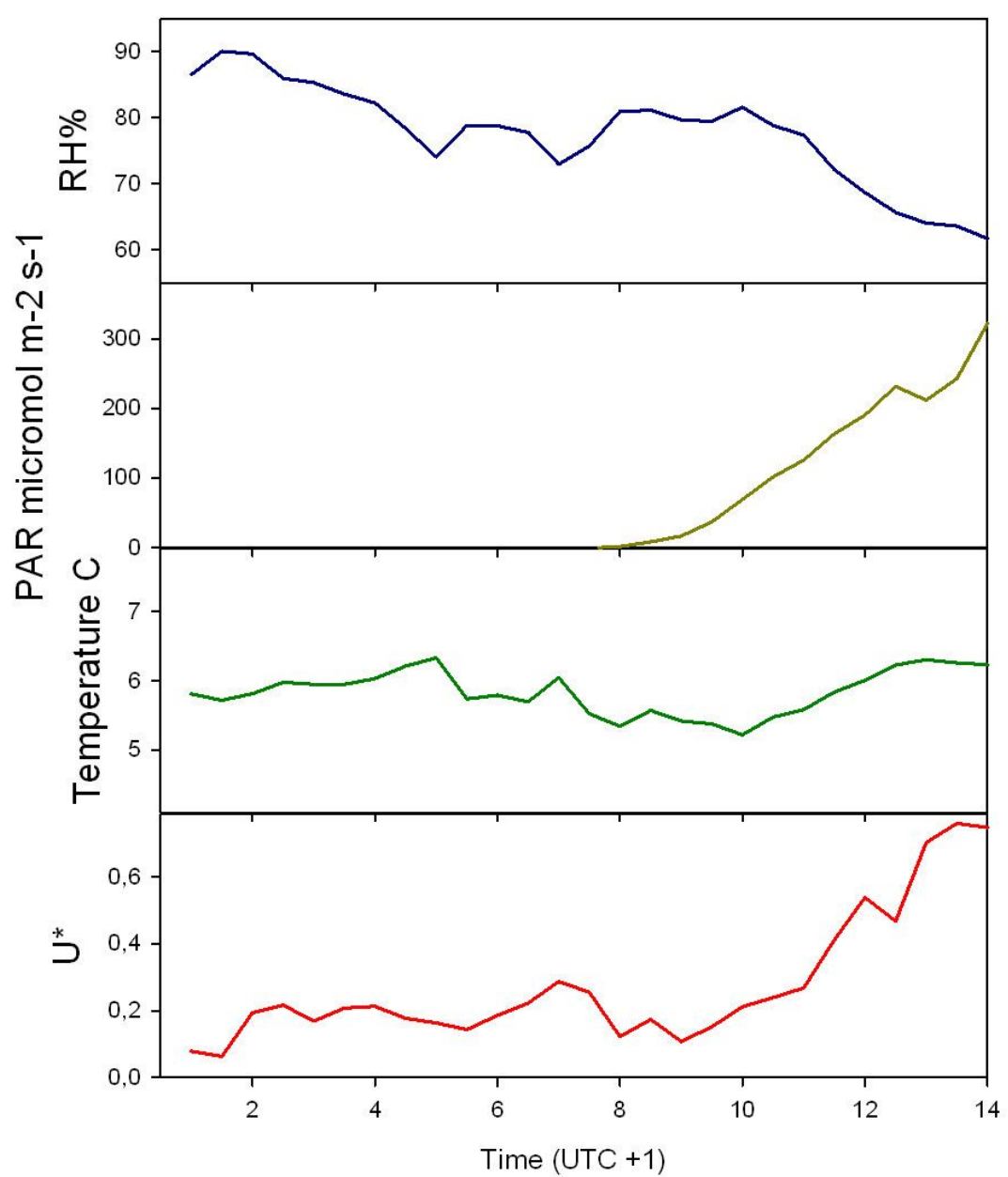

Fig. 2 - Relative humidity (RH\%), PAR, temperature and friction velocity $(u *)$ measured above the canopy in relation to time of day during the analysis period. 

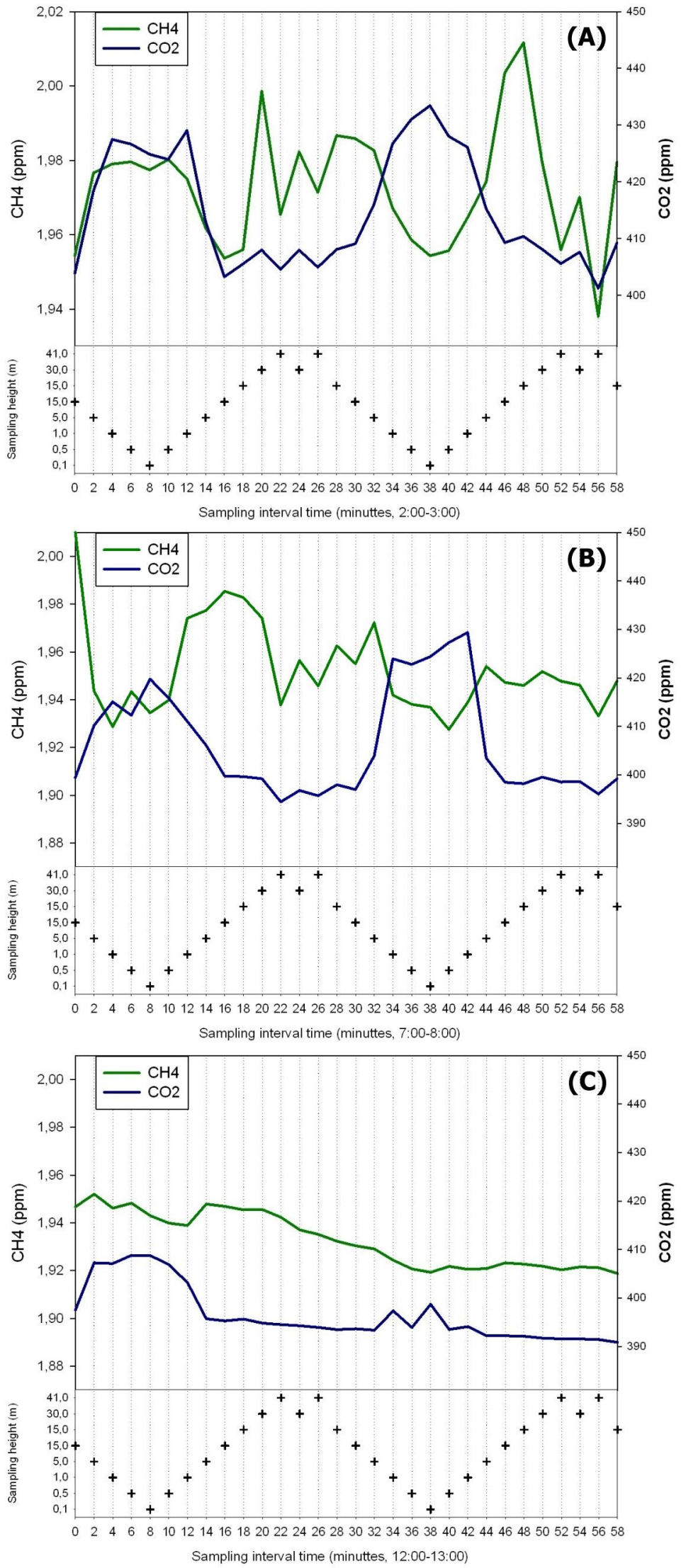

Fig. $3-\mathrm{CO}_{2}$ and $\mathrm{CH}_{4}$ concentration in the air in relation to height and time of day on three selected time periods lasting 1 hour each. and $\mathrm{C}$ the concentrations of $\mathrm{CO}_{2}$ and $\mathrm{CH}_{4}$, from the LGR analyzer, are shown in relation to sampling height and time for three selected sample hours during the analysis period. The sample periods represent night time at calm conditions (Fig. 3A, 3B) and day time conditions with an increasing $u_{*}$ (Fig. 3C). In Fig. 3A, 3B and 3C the $\mathrm{CO}_{2}$ concentration is highest near the forest floor and decreases in the canopy and is lowest above the canopy. The $\mathrm{CH}_{4}$ concentrations are much more variable than $\mathrm{CO}_{2}$, but in general, lowest at the forest floor and highest in the canopy and above the canopy. The processes in the soil play important roles for the development of air concentrations of both $\mathrm{CO}_{2}$ and $\mathrm{CH}_{4}$ above the soil. In this forest it is documented that there is a constant upward $\mathrm{CO}_{2}$ flux due to microbial and root respiration and a constant downward flux of $\mathrm{CH}_{4}$ due to microbial oxidation (Pilegaard et al. 2003). The bell shaped curve for $\mathrm{CO}_{2}$ in relation to sampling height is less explicit in Fig. 3C due to a higher rate of air mixing, but still very clear and it is also possible to detect the inverse relationship for $\mathrm{CH}_{4}$. Here, the increased air mixing reduces the gradients but it also reduces the concentration variations for both gasses. In Fig. 4 a contour plot shows the vertical $\mathrm{CO}_{2}$ concentration for the complete analysis period. The $\mathrm{CO}_{2}$ concentration is high in the lower part of the forest and reaches its maximum near the forest floor. The concentration gradient vanish when $u_{*}$ exceeds $0.5 \mathrm{~m} \mathrm{~s}^{-1}$ around noon. In Fig. 5 a contour plot shows the vertical $\mathrm{CH}_{4}$ gradients for the complete analysis period. Low concentrations near the forest floor can be seen and higher concentrations are detected in the canopy, shown as "islands", with higher concentrations around 1:30, 7:00, 9:00 and 11:30 o'clock. Also here the concentration gradient vanishes when $u *$ exceeds $0.5 \mathrm{~m} \mathrm{~s}^{-1}$.

\section{Discussion}

Methane is produced when plant material is exposed to UV light and there is also a parallel $\mathrm{CH}_{4}$ emission that increases with increasing temperature (Vigano et al. 2008, Bruhn et al. 2009). To document and quantify this in the field is a major task because the emission is small compared to the atmospheric concentration and the natural variation is high, as seen in this and others studies (Bowling et al. 2009, Smeets et al. 2009, Miyama et al. 2010). Plumes from polluted areas containing higher $\mathrm{CH}_{4}$ concentrations can be transported to forest areas as shown by Bowling et al. (2009) and Smeets et al. (2009) and this will contribute to large variations in the background $\mathrm{CH}_{4}$ concentration. Two studies find a negative vertical $\mathrm{CH}_{4}$ gradient from above the forest to the forest floor (Bowling et al. 2009, Smeets et al. 2009). A negative $\mathrm{CH}_{4}$ gradient within the 


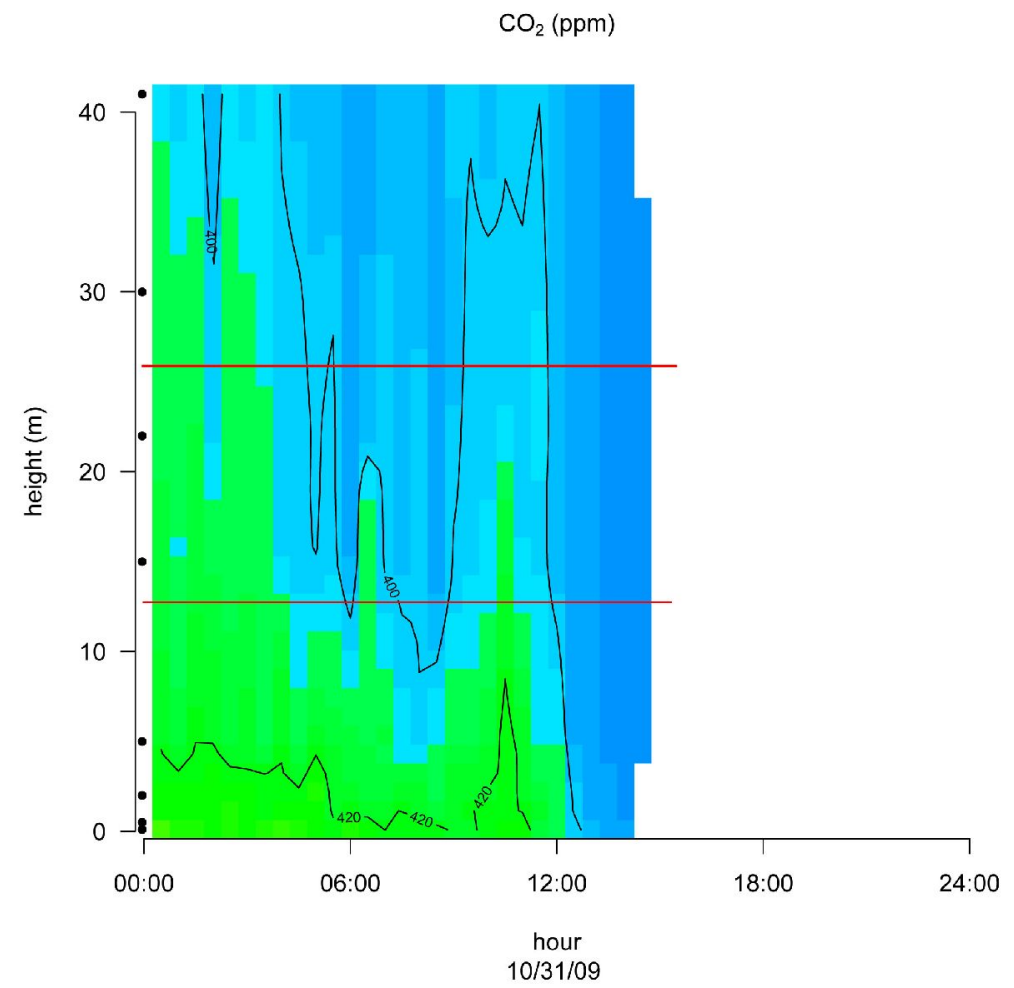

Fig. 4 - Contour plot of the vertical $\mathrm{CO}_{2}$ concentration for the complete analysis period. The horizontal red lines illustrate the top and bottom of the beech canopy. Dots on Y-axis indicate sampling inlets. $\mathrm{CO}_{2}$ concentration increases in the following order: Dark blue, light blue and green.

$\mathrm{CH} 4(\mathrm{ppm})$

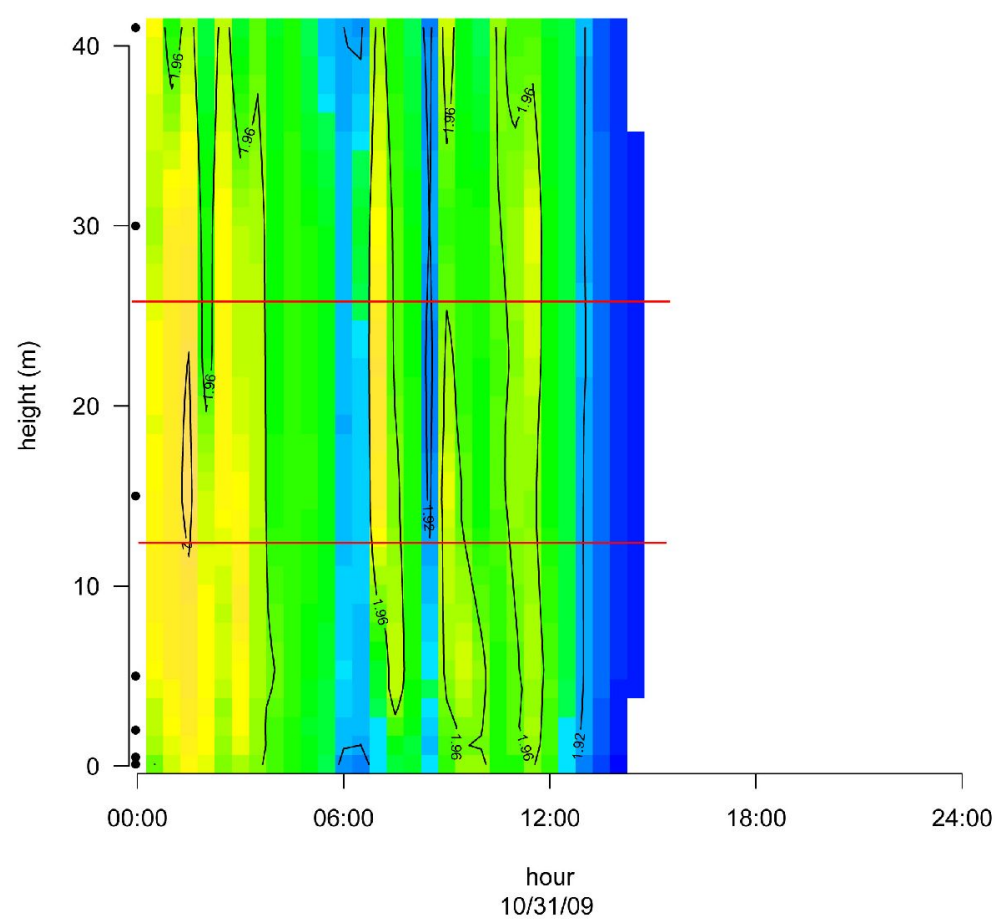

Fig. 5 - Contour plot of the vertical $\mathrm{CH}_{4}$ concentration for the complete analysis period. The horizontal red lines illustrate the top and bottom of the beech canopy. Dots on Y-axis indicate sampling inlets. $\mathrm{CH}_{4}$ concentration increases in the following order: Dark blue, light blue, green and yellow. canopy could indicate: (1) a soil $\mathrm{CH}_{4}$ sink and no canopy exchange of $\mathrm{CH}_{4} ;(2)$ a soil $\mathrm{CH}_{4}$ sink and a canopy $\mathrm{CH}_{4}$ sink; or (3) a dominant soil $\mathrm{CH}_{4}$ sink and a smaller canopy $\mathrm{CH}_{4}$ source, with relative magnitudes such that the combined net $\mathrm{CH}_{4}$ flux is a sink (Bowling et al. 2009). In our forest, and in three others studies the undisturbed forest floor is detected as a $\mathrm{CH}_{4}$ sink directly by soil chambers (Pilegaard et al. 2003, Morishita et al. 2007) or indirectly via a profile system (Bowling et al. 2009) or eddy covariance measurements (Smeets et al. 2009). The $\mathrm{CH}_{4}$ soil deposition measured over a year and reported as annual average varies from $34.2 \mu \mathrm{g} \mathrm{m}^{-2} \mathrm{~h}^{-1}$ (Pilegaard et al. 2003) to $66 \mu \mathrm{g} \mathrm{m}^{-2} \mathrm{~h}^{-1}$ (Morishita et al. 2007). The aerodynamic soil fluxes showed $70.8 \mu \mathrm{g} \mathrm{m}^{-2}$ $\mathrm{h}^{-1}$ during campaigns in July and August (Bowling et al. 2009) and $104.4 \mu \mathrm{g} \mathrm{m}^{-2} \mathrm{~h}^{-1}$ in an August campaign (Smeets et al. 2009). Simple upscaling of the aerobic $\mathrm{CH}_{4}$ production in Betula populifolia leaves (not sampled at the Soroe site) from the laboratory study at $20{ }^{\circ} \mathrm{C}$ (Bruhn et al. 2009) gives approximately $2 \mathrm{ng} \mathrm{CH}_{4} \mathrm{~g} \mathrm{dw}^{-1} \mathrm{~h}^{-1}$ in dark and $6 \mathrm{ng} \mathrm{CH}_{4} \mathrm{~g} \mathrm{dw}^{-1} \mathrm{~h}^{-1}$ in medium light. For a canopy with a $\mathrm{LAI}=5$ this will give $2+2+$ $2+2+6=14 \mathrm{ng} \mathrm{CH}_{4} \mathrm{~g} \mathrm{dw}^{-1} \mathrm{~h}^{-1}$, since only one leaf layer is expose to direct UV light. If the Specific Leaf Area (SLA) is estimated to 140 $\mathrm{cm}^{2} \mathrm{~g}^{-1}$ the $\mathrm{CH}_{4}$ emission from the leaves in the canopy will be $1.0 \mu \mathrm{g} \mathrm{CH}_{4}$ ground $\mathrm{m}^{-2}$ $\mathrm{h}^{-1}$. This number could be higher at more natural conditions if, e.g., emissions from branches, stems, leaf buds, and litter are included, but experimental data are lacking here. However, we hypothesize that the canopy emission and the soil uptake is likely a case nr. 3 with a dominant soil $\mathrm{CH}_{4}$ sink and a smaller canopy $\mathrm{CH}_{4}$ source, with relative magnitudes such that the combined net $\mathrm{CH}_{4}$ flux is a sink according to Bowling et al. (2009). This will make it almost impossible to determine an aerobic canopy $\mathrm{CH}_{4}$ emission by use of normal aerodynamic methods. In our study we focus on days with windless conditions and in the $\mathrm{CH}_{4}$ contour plot (Fig. 5) several "islands" with high $\mathrm{CH}_{4}$ concentrations are detected around canopy height over the 12 hour period. This could be an indication of a canopy $\mathrm{CH}_{4}$ production since the calm conditions allow a $\mathrm{CH}_{4}$ concentration build up. It is notably, that the three first concentration build-ups in the canopy are generated in the dark or at very low light conditions and at low temperature. Under these conditions a very low $\mathrm{CH}_{4}$ production is expected from the laboratory experiments (Bruhn et al. 2009). At 11:30 the PAR level is increased to a level were also $\mathrm{CH}_{4}$ production from direct UV light is expected (Bruhn et al. 2009). However, unfortunately the $\mathrm{CH}_{4}$ build up is without the possibility for a quantification of the production rate with the current method. Using profile measurement 
inside a forest cannot yet be used for flux rate estimation unless the diffusion coefficient can be estimated. In calm weather conditions, when extreme stabilities are likely to occur, this is even difficult above canopies. The heterogeneous environment inside a forest (stems, leaves, branches, etc.) influence the aerodynamic transport with varying intensities due to variations in wind speed, wind direction, heat flux, turbulence, etc. In general these methods only work in stationary conditions, meaning that the background $\mathrm{CH}_{4}$ concentration doesn't change. A change in background concentration with time will also lead to vertical concentration gradients, until atmospheric mixing leads to equilibrium between surface fluxes, atmospheric transport and vertical concentration profiles. Averaging over a larger data set would possibly help to test our hypothesis with higher accuracy.

However, despite these limitation, we found the lower $\mathrm{CH}_{4}$ concentrations closer the forest floor to be a plausible indicator for the expected soil $\mathrm{CH}_{4}$ uptake (Fig. 3A, 3B and Fig. 5) and the $\mathrm{CO}_{2}$ build up at the forest floor (Fig. 4), and conclude that the measuring system detects concentration profiles that would be expected in a normally functioning forest ecosystem. This supports our profile observation showing that $\mathrm{CH}_{4}$ emission occurs in the canopy. Nevertheless, this was only seen in one campaign due to the special demands for windless conditions and the pattern that shows a canopy build up must be repeatedly shown to detect a $\mathrm{CH}_{4}$ production in the canopy. An improvement of the profile system will include more sampling within the canopy layer. The current profile only include one sampling inlet in the canopy while the 6 other sampling inlets are situated above and below the canopy. One or two additional sampling inlets in the canopy will undoubtedly increase the detail level and provide a better understanding how and when the "islands" with higher $\mathrm{CH}_{4}$ concentrations are created and if the canopy can be categorized as a permanent $\mathrm{CH}_{4}$ source. The system will however not be able to quantify any canopy fluxes.

\section{Conclusions}

We asked in the headline: is methane released from the forest canopy? and answer Yes, that is very likely since firm evidence has been produced in the laboratory (Vigano et al. 2008, McLeod et al. 2008, Bruhn et al. 2009, Vigano et al. 2009), and consequently this must also be expected in the canopy in the field under natural conditions. In this study, we see indications for $\mathrm{CH}_{4}$ emissions from the canopy, but more data are needed to be analyzed before the canopy can be considered as a $\mathrm{CH}_{4}$ source or not. Additionally, more controlled experiments under realistic light conditions with a variety of plants are needed to corroborate the hypothesis of small $\mathrm{CH}_{4}$ emissions. However, given the new reduced $\mathrm{CH}_{4}$ emission estimates from laboratory experiments and the large difficulties to quantify such $\mathrm{CH}_{4}$ emissions in the field, one can probably conclude that the small $\mathrm{CH}_{4}$ emissions from leaves are far from offsetting the climate cooling effects of forest due to $\mathrm{CO}_{2}$ sequestration.

\section{Acknowledgements}

We acknowledge funding from the EU projects NitroEurope and IMECC for the used scientific infra structures. The concentration profile system was partly maintained by colleagues from Risø DTU's Wind Energy Department, namely Søren W. Lund and Ebba Dellwik. We acknowledge gratefully generous access to the site granted by the owner, Sorø Akademi, and supported by forest manager Anders Grube and director Jens K. Poulsen.

\section{References}

Bloom AA, Lee-Taylor J, Madronich S, Messenger DJ, Palmer PI, Reay DS, McLeod AR (2010). Global methane emission estimates from ultraviolet irradiation of terrestrial plant foliage. New Phytologist 187: 417-425. - doi: 10.1111/j.14698137.2010.03259.x

Bowling DR, Miller JB, Rhodes ME, Burns SP, Monson RK, Baer D (2009). Soil, plant, and transport influences on methane in a subalpine forest under high ultraviolet irradiance. Biogeosciences 6: 1311-1324. - doi: 10.5194/bg-61311-2009

Bruhn D, Mikkelsen TN, Øbro J, Willats WG, Ambus P (2009). Effects of temperature, ultraviolet radiation and pectin methyl esterase on aerobic methane release from plant material. Plant Biology 11: 43-48. - doi: 10.1111/plb. 2009.11.issue-s1

Dellwik E, Jensen NO (2000). Internal equilibrium layer growth over forest. Theoretical and Applied Climatology 66: 173-184. - doi: 10.1007 /s007040070023

Dlugokencky EJ, Houweling S, Bruhwiler L, Masarie KA, Lang PM, Miller JB, Tans PP (2003). Atmospheric methane levels off: temporary pause or a new steady-state? Geophys. Res. Lett. 30 (19):1992. - doi: 10.1029/2003GL018126

Dlugokencky EJ, Bruhwiler L, White JWC, Emmons LK, et al. (2009). Observational constraints on recent increases in the atmospheric $\mathrm{CH}_{4}$ burden, Geophys. Res. Lett. 36: L18803. doi: 10.1029/2009GL039780

Etheridge DM, Steele LP, Francey RJ, Langenfelds RL (1998). Atmospheric methane between 1000 A.D. and present: Evidence of anthropogenic emissions and climatic variability. J. Geophys. Res. 103 (D13): 15.979-15.993. - doi: 10.1029/98JD00923

Forster P, Ramaswamy V, Artaxo P, Berntsen T, Betts R, Fahey DW, Haywood J, Lean J, Lowe DC, Myhre G, Nganga J, Prinn R, Raga G, Schulz M, Van Dorland R (2007). Changes in atmospheric constituents and in radiative forcing. In: "Climate change 2007: the physical science basis" (Solomon S, Qin D, Manning M, Chen Z, Marquis M, Averyt KB, Tignor M, Miller HL eds). Contribution of Working Group I to the $4^{\text {th }}$ assessment report of the Intergovernmental Panel on Climate Change. Cambridge University Press, Cambridge, UK and New York, NY, USA.

Keppler F, Hamilton JTG, Braß M, Röckmann T (2006). Methane emissions from terrestrial plants under aerobic conditions. Nature 439: 187-191. - doi: 10.1038/nature04420

Kirschbaum MUF, Bruhn D, Etheridge DM, Evans JR, Farquhar GD, Gifford RM, Paul KI, Winters AJ (2006). A comment on the quantitative significance of aerobic methane release by plants. Functional Plant Biology 33: 521-530. doi: 10.1071/FP06051

McLeod AR, Fry SC, Loake GJ, Messenger DJ, Reay DS, Smith KA, Yun BW (2008). Ultraviolet radiation drives methane emissions from terrestrial plant pectins. New Phytologist 180: 124132. - doi: 10.1111/j.1469-8137.2008.02571.x

Miyama T, Hashimoto T, Kominami Y, Nakagawa K, Okumura M, Tohno S (2010). Temporal and spatial variations in $\mathrm{CH}_{4}$ concentrations in a Japanese warm-temperate mixed forest. Journal of Agricultural Meteorology 66: 1-9. - doi: 10.2480/agrmet.66.1.1

Morishita T, Sakata T, Takahashi M, Ishizuka S, Mizoguchi T, Inagaki Y, Terazawa K, Sawata S, Igarashi M, Yasuda H, Koyama Y, Suzuki Y, Toyota N, Muro M, Kinjo M, Yamamoto H, Ashiya D, Kanazawa Y, Hashimoto T, Umata H (2007). Methane uptake and nitrous oxide emission in Japanese forest soils and their relationship to soil and vegetation types. Soil Science and Plant Nutrition 53: 678-691. - doi: 10.1111/ j.1747-0765.2007.00181.X

Pilegaard K, Mikkelsen TN, Beier C, Jensen NO, Ambus P, Ro-Poulsen H (2003). Field measurements of atmosphere-biosphere interactions in a Danish beech forest. Boreal Environment Research 8: 315-333. [online] URL: http://www. borenv.net/BER/pdfs/ber8/ber8-315.pdf

Smeets CJPP, Holzinger R, Vigano I, Goldstein AH, Röckmann T (2009). Eddy covariance methane measurements at a Ponderosa pine plantation in California. Atmos. Chem. Phys. 9: 8365-8375. [online] URL: http://igitur-archive. library.uu.nl/phys/2010-0514-200206/acp-98365-2009.pdf

Vigano I, van Weelden H, Holzinger R, Keppler F, Röckmann T (2008). Effect of UV radiation and temperature on the emission of methane from plant biomass and structural components. Biogeosciences Discussions 5: 243-270. - doi: 10.5194/bgd-5-243-2008

Vigano I, Röckmann T, Holzinger R, Van Dijk A, Keppler F, Greule M, Brand WA, Geilmann H, Van Weelden H, et al. (2009). The stable isotope signature of methane emitted from plant material under UV irradiation. Atmos. Environ. 43 (35): 5637-5646. - doi: 10.1016/j.atmosenv.2009.07. 046 